\title{
How to measure political gnosis? Empirical evidence from Putin's Russia ${ }^{1}$
}

\begin{abstract}
The research applies a method of sources analysis that draws upon a qualitative comparative study of three speeches delivered by Russia's President Vladimir Putin during his annual news conferences. It aims to solve the problems: how was political gnosis changing in Putin's statements over the subsequent 2014-2016 meetings? And how was Putin triggering off a performative potential of presumably non-gnostic elements of discourse to enhance political gnosis? It identifies the drift from authoritarian to totalitarian and democratic gnosis and recognizes a moderate extent of the intensity of political gnosis. The article contributes to political sociology by creating and testing the empirical effectiveness of a research tool for measuring the types and intensity of political gnosis, and distinguishing between political diagnosis and gnosis.
\end{abstract}

Key words: political religion, epistemic apparatus, semantic structure, political regime, Putin's annual news conferences

\section{Introduction and Methodological Assumptions for the Research}

$\mathbf{R}^{\mathrm{c}}$ ecent works have revealed the limitations of Juan Linz's research tool for measuring ideology, mentality, and Weltanschauung as defining properties of totalitarianism and authoritarianism and studying variations between democratic and non-democratic political thinking (Miley, 2011). However, they have also introduced promising directions of its development. Linz's critics reflected no homogeneous criteria for a distinction between ideology and mentality, their incomparability arising from the absence of shared essential features that would take on various values depending on a type of a regime (Miley, 2015; Fagerholm, 2016), imprecisely determined semantic fields (Barceló, 2017), leaving aside democracy, normative assessment of totalitarianism as the worst system, and empirical ineffectiveness in comparative studies (Miley, 2011, p. 34). The article takes advantage of the criticism and employs a conceptual framework of a sociology of religion to devise an original model of political diagnosis and gnosis. Those terms are not value-laden but treated as theoretical categories. In contrast to the existing approaches (Bäcker, 2016, p. 14), the article argues that political gnosis is not a characteristic of totalitarianism, but there are totalitarian, authoritarian, and democratic types of political gnosis. Additionally, the analysis does not strive for measuring political awareness because of uncharted differences between thinking and manifested thinking. Instead, it concentrates on oral expressions of political epistemic apparatuses and thereby omits

${ }^{1}$ This paper is a result of the research project "Contemporary Russia: Between Authoritarianism and Totalitarianism" funded by National Science Centre, Poland. The research grant number: 2015/19/B/HS5/02516. 
a problem of an extent of the internalization of semantic structures. It defines political epistemic apparatuses as the sets of beliefs determining the interpretation of social reality and considered to be knowledge. The research distinguishes its two breeds: political diagnosis and gnosis. The latter vary in hard core political values which draw upon semantic resources of democracy, authoritarianism, and totalitarianism. Although gnosis is not the only and sufficient feature to study regimes, it is their indicator as long as it presents semantic structures of the distributed understanding of political reality.

The objectives of the article are to formulate a research tool for measuring the types and intensity of political gnosis and distinguishing between political diagnosis and gnosis, apply it to examine to what extent political gnosis in Vladimir Putin's statements was democratic, authoritarian, and totalitarian and how intense it was. The study tests the empirical effectiveness of the device by assessing how well it performs its methodological function within an analysis.

Research problems are of how was political gnosis changing in Putin's speeches over the subsequent annual news conferences? And how was Putin triggering off a performative potential of presumably non-gnostic elements of discourse to enhance political gnosis? The first hypothesis assumes the president might have reconfigured political gnosis in its essential features to the extent that it drifted from an authoritarian to totalitarian type, and its intensity and frequency might have increased. Configurations of values might have altered along with the repressiveness of Russian political regime. Second, Putin might have made use of a performative potential of supposedly non-gnostic elements of discourse by reshaping them into a value-based political gnosis. The politician might have fed political gnosis by outwardly non-gnostic discourse. The non-gnostic message might have been substantially different from pure political diagnosis. Also, $\mathrm{Pu}-$ tin might have taken advantage of some types of political gnosis to produce another.

The research applies a method of sources analysis that draws on a qualitative comparative study of three speeches delivered by Putin during his annual news conferences between February 20, 2014, and March 26, 2017. The initial caesura is the beginning of Russian military intervention in Ukraine, the empowerment of a vested interest in perpetuating a total enemy of Russia, maintaining sharp divisions between "we" and "they" in public discourse, and determining politico-soteriological goals (Roberts, 2017; Sussex, 2017). The closing caesura is another substantial incentive to brace or change discursive strategies because of a massive wave of protests against current political elites and alleged corruption that might have contributed to a revolutionary situation (Motimele, 2017; Kolstø, 2016).

The conferences were staged for Russian and foreign journalists accredited in Russia. Putin answered questions from reporters, other people in the studio, and spectators from across the country. The Press Secretary for the President of Russia decided who asked and set an order of questions. In contrast to other Putin's meetings (e.g., the so called Priamaja linia, the Q\&A for Russians), conferences were not wholly centrally controlled. However, even if participants were not expected to table proposals for issues before a conference, their subject matter was highly predictable. The Q\&A form of meetings gives the research the opportunity to observe how Putin produced political gnosis and how he took advantage from presumably non-gnostic elements of discourse to back the discursive structures of gnosis. 
The relational content analysis uses original research tools to collect and elaborate data necessary and sufficient to solve the research problems. A categorization key to content analysis serves to abstract the political diagnosis and gnosis, including democratic, authoritarian, and totalitarian elements of semantic resources from stenographic records of the conferences. Then, a theoretical framework of gnosis enables us to determine manifestations of political gnosis, intensity, and dissimilarities between its three types.

\section{Conceptualizing, Operationalizing, and Measuring Political Gnosis}

The article creates scales by the criteria of primary political values for regimes and values of the distinctive qualities of gnosis. The first allows us to identify the configuration of democratic, authoritarian, and totalitarian components in political gnosis. The second applies to determine their intensity. Both indicate the configurations of diagnostic and gnostic epistemic apparatuses. The research adopts a concept-driven coding method to recognize in Putin's speeches the oral utterances of a conceptual framework. Codes are of a theoretical and qualitative genre. Statements which do not have key hallmarks of political gnosis but fulfill essential parameters for political diagnosis are coded as the latter. The characteristics of political gnosis are splitting the political universe into the good internal world and the evil external world, fallacious immanentization of the eschaton, manifestations of presumed anomie among a populace, political obscurantism as a mode of dealing with dangerous knowledge, and strategies of survival on the historic battlefield. Each of them takes on values (qualitative quantities assigned to a feature) that contribute to the extent of the intensity of political gnosis. The most frequently represented values are dominant, and as such, they perform an indicating role to assess the intensity.

A wording is coded as democratic gnosis when satisfies the criteria for political gnosis and refers to democratic values (liberty, freedom, equalities, justice, human rights, civil rights) and institutions (universal franchise on a one-person, one-vote basis, regular and contested voting operating at two distinct levels of parliament and general elections, and majority rule) (Martin, 1997), totalitarian - the country, state, Russia, statehood, and authoritarian - the nation, Russian, and people. The words sharing semantic fields with the mentioned categories have a status of indicators equal to them (e.g., Russia and Russian Federation).

\section{Types of Political Gnosis}

During the conferences, Putin created a political universe remarkably consistent with those he disseminated in other communicational situations (Dyson, Parent, 2017, p. 6). The employment of the conceptual framework of democratic, authoritarian, and totalitarian gnosis shows the distribution of oral manifestations that both met essential features of political gnosis and drew upon democratic institutions and values, nation or state. Though some utterances complied with the criteria for political gnosis, they were neither democratic nor non-democratic because Putin did not anchor them in the direct refer- 
ences to the core political values of the regimes. As a result, Putin's speeches embodied more expressions of general gnosis than democratic, authoritarian, and totalitarian types in all. The general form, however, empowered the particular ones by supporting their narrative constructions. The elements of political diagnosis performed the same function but were in the minority. For the sake of clarity, their count was smaller than a number of individual components of political diagnosis because that part of the analysis addressed the holistic visions of reality. Despite the scope of images, they lent weight to the arguments for the immanentization of the Russian World.

Table 1

The configuration of the elements of political gnosis and diagnosis in Putin's annual news conferences

\begin{tabular}{|l|r|r|r|}
\hline \multirow{2}{*}{$\begin{array}{c}\text { A type of epistemic } \\
\text { apparatus }\end{array}$} & \multicolumn{3}{|c|}{ A count of manifestations } \\
\cline { 2 - 4 } & $\mathbf{2 0 1 4}$ & $\mathbf{2 0 1 5}$ & $\mathbf{2 0 1 6}$ \\
\hline Democratic gnosis & 3 & 0 & 12 \\
\hline Authoritarian gnosis & 178 & 143 & 163 \\
\hline Totalitarian gnosis & 103 & 84 & 28 \\
\hline Political diagnosis & 62 & 43 & 118 \\
\hline
\end{tabular}

Source: Own study.

In $2014,82 \%$ of the references to a political universe was political gnosis, in 2015 $-84 \%$, and in $2016-91 \%$ (Table 1). Whereas the frequency of gnostic manifestations increased, the rate of political diagnosis decreased. The configuration of gnostic and diagnostic elements in Putin's speeches did not reflect changes in Russian domestic and foreign politics. Political events that were in the public eye in 2014, such as Russian military intervention in Ukraine, did not affect the oral construction of a political universe significantly.

In $2014,1 \%$ of the elements of political gnosis were democratic, $63 \%$ - authoritarian, and 36\% - totalitarian. In 2015, 63\% - authoritarian and 37\% - totalitarian. In 2016, $4 \%$ - democratic, $56 \%$ - authoritarian, and $40 \%$ - totalitarian. Not in the whole period, authoritarian political gnosis was dominant. Its frequency declined about 7 percentage points from 2014-2015 to 2016. The extent of totalitarianism and democracy in gnostic semantic structures mounted slightly.

In using democratic gnosis, in 2014, Putin referred twice to economic freedom for entrepreneurs and once to social justice. In 2015, no element of democratic gnosis entered Putin's speech. In 2016, there were 12 references to equal rights of citizens, social, juvenile, and political justice (e.g., "About the prosecution bias in justice in Russia. You know, we have recently taken a lot of decisions aimed at humanising our legislation. This applies to criminal law, to administrative offenses, and additional measures are being taken now" (Putin, 2016)).

Much more frequently Putin exerted totalitarian gnosis. In 2014, 48\% of the manifestations of totalitarian gnosis referred to Russia, $33 \%$ - the country, and $19 \%$ - the state. In $2015,41 \%$ of the images of totalitarian gnosis concerned Russia, $36 \%$ - the country, and $23 \%$ - the state. In $2016,47 \%$ of the articulations of totalitarian gnosis related to Russia, 33\% - the country, and 20\% - the state (e.g., "An aggressor is someone who can 
attack the Russian Federation. We are stronger than any potential aggressor. I have no problem repeating it" (Putin, 2016)).

Authoritarian gnosis was dominant in 2014 and 2015. In 2014, 12\% of the expressions of that type concerned the nation, 55\% - the people, and 33\% - things defined as Russian (e.g., "but for the benefit of the nation and people. This is the aim" (Putin, 2014)). In 2015, $13 \%$ of the articulations of authoritarian gnosis related to the nation, $63 \%$ - the people, and $24 \%$ - the predicate of Russian. In 2016, $13 \%$ of the elements of authoritarian gnosis referred to the nation, $49 \%$ - the people, and 38\% - things called Russian.

Putin reconfigured political gnosis in its core political values, and thus it drifted from authoritarian to democratic and totalitarian types. From 2014 to 2015, authoritarian gnosis was the lead epistemic apparatus and, additionally, demonstrated a growing tendency in 2016. Totalitarianism dominated in 2016 but remained in a fixed configuration with strong, well-established, and frequent authoritarianism. Even though Putin ceaselessly benefited from political diagnosis, the frequency of the application of non-gnostic elements to support gnostic narration was declining.

\section{Intensity of Political Gnosis}

The first essential feature of political gnosis is a distinction between the good internal world and the evil external world, including things, people, and their political values. The differentiation of the elements of a political universe is a consequence of the semantic creation of the intrinsically either acceptable or unacceptable beings and phenomena. The analysis adopts a broadly inclusive approach toward the worlds by not introducing the subcategories of the elements. On the level of the distinction between the worlds, two homogeneous criteria of the positive valorization of the inside world and the negative valorization of the outside world let us recognize the extents of the intensity of political gnosis. The values of the distinction between the inner and outer worlds are: a maximum extent of political gnosis, sacralization of the internal world and devilization of the external world (3) is when the gnostic sanctifies the interior world so much so that it becomes the sacred, the greatest thing in a universe. An antinomic process focuses on the exterior world. The gnostic damns it so much so that it is to an extreme degree infernal evil. Superlative adjectives used to create the worlds in that way indicate the highest intensity of gnosis. A moderate extent, melioration of the internal world and pejorativization of the external world (2) is when the gnostic displays affectionate and frenetic allegiance to the worlds under valorizing, either positive or negative. The gnostic designs the worlds by exalted manifestations of worship or revulsion respectively. Comparative and positive adjectives serve as a means of oral construction. In a low extent, defensive relativization of the internal world and offensive relativization of the external world (1), the gnostic treats the elements of the internal world like not as wicked as others. The strategy utilizes comparisons to convince people that they are better against the background of others, just like the remaining elements of "their world." Offensive relativization of the evil external world makes of the same mechanism. Positive components of the outer world are not as positive as others. The comparison of features depreciates that world. When an idea does not contain the division-based discursive creation and is relatively close to a political di- 
agnosis of reality [0], no political gnosis emerges. Description of the features marks the range of political gnosis determined by the extents of its intensity with round brackets. A political diagnosis is marked with square brackets. The defining features of political gnosis and diagnosis mark out boundaries between the categories.

Table 2

Political reality in Putin's annual news conferences

\begin{tabular}{|c|c|c|c|}
\hline \multirow{2}{*}{$\begin{array}{c}\text { The intensity of political gnosis/lack of political } \\
\text { gnosis }\end{array}$} & \multicolumn{3}{|c|}{ 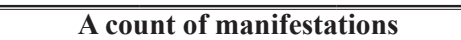 } \\
\hline & 2014 & 2015 & 2016 \\
\hline \multicolumn{4}{|l|}{$\begin{array}{ll} & \text { Political gnosis } \\
\end{array}$} \\
\hline $\begin{array}{l}\text { Sacralization of the internal world and devilization of the } \\
\text { external world }\end{array}$ & 32 & 20 & 19 \\
\hline $\begin{array}{l}\text { Melioration of the internal world and pejorativization of } \\
\text { the external world }\end{array}$ & 124 & 110 & 98 \\
\hline $\begin{array}{l}\text { Defensive relativization of the internal world and offen- } \\
\text { sive relativization of the external world }\end{array}$ & 73 & 67 & 68 \\
\hline \multicolumn{4}{|c|}{ Political diagnosis } \\
\hline Political diagnosis of reality & 42 & 56 & 48 \\
\hline
\end{tabular}

Source: Own study.

The configuration of gnostic and non-gnostic elements in Putin's statements indicates that the former dominated in the whole period (Table 2). Putin kept political diagnosis down. In 2014, $15 \%$ of the manifestations concerning political reality were of diagnostic nature, in $2015-22 \%$, and in $2016-21 \%$. The moderate extent of political gnosis came first from among other values of the distinction between the internal and external worlds from 2014 to 2016. In 2014, 46\% of the articulations drew upon melioration and pejorativization (e.g., "Let me remind you about the preparations for the 2014 Olympics, our inspiration and enthusiasm to organise a festive event not only for Russian sports fans, but for sports fans all over the world. However, and this is an evident truth, unprecedented and clearly orchestrated attempts were made to discredit our efforts to organise and host the Olympics. This is an undeniable fact!" (Putin, 2014)). Although in the next year fewer expressions had that value, it remained dominant. In 2015, 43\% of the projections took on the average value, in $2016-42 \%$. It reflects steadiness in the value's share in the configurations of the semantic creations of a political universe. The mildly valorizing interpretation of politics showed sharp divisions between its actors and communicated promptitude. Simultaneously, it was a sign of feeling secure, being tough, driving, and having a sense of duty to protect the internal world from the specific components of the hostile forces.

Less numerous was defensive and offensive relativization. A fractional decrease in the use of that type of manifestations occurred between 2014 and 2016. In 2014, 27\% of the images took on a low extent, in $2015-27 \%$, and in $2016-29 \%$. So, the value's part in the configurations maintained (e.g., "Now about alcohol abuse. Yes, indeed, it is a problem. However, oddly enough, it may not be as bad as in some other countries, particularly, Northern Europe" (Putin, 2016)).

Sacralization and devilization were the least frequent distinguishing between the worlds (e.g., "after the fall of the Berlin Wall and the breakup of the Soviet Union, Russia opened itself to our partners. What did we see? A direct and fully-fledges support of terrorism in 
North Caucasus. They directly supported terrorism, you understand?" (Putin, 2014)). Also, it was not as numerous as a political diagnosis. In $2014,12 \%$ of the wordings took on the highest value, in $2015-8 \%$, in $2016-8 \%$. The role of the extreme value slightly dropped over time but was invariant between 2015 and 2016. Its configuration with other values indicates that Putin perceived no political subject as fully capable of challenging the status quo, which reflects no fear of a revolutionary situation (Colgan, Lucas, 2017).

Whereas the first feature of political gnosis focuses on the existing reality, the next one approaches the design and performance of its future shape which is the eschaton. The gnostic fallaciously immanentizes the eschaton - here a vision of the Great Russia that is to appear "in the near future" (Putin, 2014) - by projecting a politico-eschatological idea of the world and implements a policy to actualize them (Voegelin, 1987, p. 166). Political gnosis is gradable by a variant of the immanentization which fills the gnostic's life with sense. The distinction is a result of a semantic creation of what political reality should dawn and how to obtain the dreamful state. On the level of the fallacious immanentization, a homogeneous criterion of the feasibility of the eschaton enables us to distinguish four levels of the intensity of political gnosis.

The scale is founded on Voegelin's variants of fallacious immanentization: active mysticism, utopianism, and progressivism (1987). However, it adds eutopianism to the set to enhance its empirical effectiveness. The feature takes on the following values: a maximum extent, active mysticism (4) is the performance of a fully unrealistic vision of the eschaton. The gnostic declares the use of available and inaccessible means to perform it. A high extent, utopianism (3) is when the gnostic frames a wholly unrealistic view of the eschaton and declares the deployment of available means to actualize it. A moderate extent, eutopianism (2) creates a realistic image of the eschaton and makes declarations of the actualization of the eschaton. The gnostic appeals for employing the available means. A low extent, progressivist immanentization (1) focuses on the realistic but not well-defined eschaton and a movement toward a goal. The progressivist gnostic avoids providing clarity about ultimate perfection, takes a selection of desirable factors as the standard, and interprets progress as a qualitative and quantitative rise of the present good-the "bigger and better." Whereas the gnostic constitutes a heaven on earth, the diagnostic does not form unrealistic expectations. When an expression is not the eschaton-based discursive creation and is relatively close to a political diagnosis of prospective political reality [0], no political gnosis occurs.

Table 3

Fallacious immanentization of the eschaton in Putin's annual news conferences

\begin{tabular}{|c|c|c|c|}
\hline \multirow{2}{*}{ The intensity of political gnosis/lack of political gnosis } & \multicolumn{3}{|c|}{ A count of manifestations } \\
\hline & 2014 & 2015 & 2016 \\
\hline \multicolumn{4}{|l|}{ Political gnosis } \\
\hline Active mysticism & 0 & 0 & 0 \\
\hline Utopianism & 0 & 0 & 0 \\
\hline Eutopianism & 96 & 84 & 82 \\
\hline Progressivism & 142 & 138 & 130 \\
\hline \multicolumn{4}{|l|}{$\begin{array}{ll} & \text { Political diagnosis } \\
\end{array}$} \\
\hline Political diagnosis of current efforts to develop a political community & 48 & 67 & 65 \\
\hline
\end{tabular}

Source: Own study. 
The configuration of gnostic and non-gnostic elements in Putin's statements points out that the former dominated during the whole period (Table 3). In 2014, $83 \%$ of the references to current efforts to develop political community were gnostic, in 2015 and 2016 - 77\%. After 2014, the level of political gnosis decreased and kept pace. The absence of narration satisfying the criteria for active mysticism and utopianism indicates that Putin did not outline unrealistic pictures of the eschaton. The most frequent value was progressivism (e.g., "We must work, and the external conditions are forcing us to become more efficient and to shift to innovative development" (Putin, 2014)). In 2014, it characterized $50 \%$ of the references, in $2015-48 \%$, and in $2016-47 \%$. Though eutopianism was not as frequent as progressivism, it entered Putin's speeches more often than political diagnosis (e.g. "So, it is not about Crimea but about us protecting our independence, our sovereignty and our right to exist" (Putin, 2014)). In 2014, 33\% of the expressions took on that value, in $2015-29 \%$, and in $2016-30 \%$.

The configuration of political diagnosis, eutopianism, progressivism, and the preponderancy of the latter tell Russia is on course to become the Great Russia. Immanentization does not require searching for proselytes (e.g., "I do not take support for the Russian President among a large part of Republican voters as support for me personally, but rather see it in this case as an indication that a substantial part of the American people share similar views with us on the world's organisation, what we ought to be doing, and the common threats and challenges we are facing. It is good that there are people who sympathise with our views on traditional values because this forms a good foundation on which to build relations between two such powerful countries as Russia and the United States" (Putin, 2016)). Putin avoided spelling any radical change that might have had socially unpredictable results.

The third feature of political gnosis is presumed anomie. The gnostic that creates and distributes political gnosis assumes that recipients feel anomie and refers to its suppositious features. Anomie derives from the absence of regulatory norm and evinces itself in the feelings of instability. The gnostic seeks to distribute political gnosis effectively to win political believers over and encourage them to redistribute political gnosis and thus makes provision for the properties of actual anomie to project a reflection of reality.

The scale to measure the intensity of the feature of political gnosis benefits from Arash Heydari, Iran Davoudi, and Ali Teymoori's set of indicators of anomie (2011). The authors establish three primary groups of indicators: meaninglessness and distrust, powerlessness, and fetishism of money. Eight statements give voice to meaninglessness and distrust: "I can trust to the statements of high-ranking officials (authority)," "There is little use writing to public officials because often they aren't really interested in the problems of average men," "In spite of what some people say, a lot of average men is getting worse, not better," "I believe most of the congress bills are toward the welfare of people," "Most public officials (people in public office) are not really interested in the problems of the average man," "I often wonder what the meaning of life really is," "It's hardly fair to bring children into the world with the way things look for future," "Everything is relative, and there just aren't any definite rules to live by." Powerlessness expresses itself in seven statements: "I lead a trapped or frustrated life," "Nobody knows what is expected of him or her life," "I have no control over my destiny," "The socioeconomic status of people determines their dignity and its inevitable," "The world is changing so fast that it 
is hard for me to understand what is going on," "My whole world feels like it as falling apart," "No matter how hard people try in life it doesn't make any difference." Fetishism of money enters five statements: "To make money, there are no right and wrong ways anymore, only easy ways and hard ways," "A person is justified in doing almost anything if the reward is high enough," "I am getting a college education so I can get a good job," "I follow whatever rules I want to follow," "Money is the most important thing in life" (Heydari, Davoudi, Teymoori, 2011, p. 1089). Images falling into the statement category are the element of political gnosis called presumed anomie.

On the level of the presumed anomie, two homogeneous criteria of the anomie indicators and statements enable us to distinguish three levels of the intensity of political gnosis. The presumed anomie takes on the following values: a maximum extent of political gnosis (3) is when the gnostic presumes anomie by extending to meaninglessness and distrust, powerlessness, and fetishism of money. At least $50 \%$ of the statements of each indicator is in use. Political gnosis achieves a moderate extent (2) when the gnostic takes advantage of two out of the three indicators and at least $50 \%$ of the statements of each one. A low extent (1) occurs when the gnostic refers to one from among the three indicators and at least $50 \%$ of its defining statements. When there is no anomie-based discursive creation of a response to the presumed anomie, and an utterance is relatively close to a political diagnosis of relative deprivations [0], no political gnosis makes an appearance.

Table 4

Presumed anomie in Putin's annual news conferences

\begin{tabular}{|c|c|c|c|}
\hline \multirow{2}{*}{ The intensity of political gnosis/lack of political gnosis } & \multicolumn{3}{|c|}{ A count of manifestations } \\
\hline & 2014 & 2015 & 2016 \\
\hline \multicolumn{4}{|l|}{ Political gnosis } \\
\hline $\begin{array}{l}\text { Three types of the anomie indicators and at least } 50 \% \text { of the statements of } \\
\text { each one }\end{array}$ & no & no & no \\
\hline $\begin{array}{l}\text { Two types of the anomie indicators and at least } 50 \% \text { of the statements of } \\
\text { each one }\end{array}$ & no & no & no \\
\hline One type of the anomie indicators and at least $50 \%$ of the statements of it & yes & yes & yes \\
\hline \multicolumn{4}{|l|}{ Political diagnosis } \\
\hline Political diagnosis of relative deprivations & 0 & 0 & 0 \\
\hline
\end{tabular}

Source: Own study.

Putin avoided employing political diagnosis to tell about relative deprivations (Table 4). Gnostic visions of presumed anomie had a low intensity because its expressions met the criteria for at least $50 \%$ of the statements of only one indicator. $100 \%$ of the statements of fetishism of money occurred in each year, in the form of 149 references in 2014, 119 - 2015, and 108 - 2016 (e.g., "If organisations that are not financial institutions at all, but money laundering vehicles, remain on the Russian market, it will do no good, and depositors will be the ones to suffer. It is for protecting the interests of individuals that the deposit insurance system was introduced" (Putin, 2016)).

In 2014-2016, 12,5\% of the indicatory statements of the meaninglessness and distrust occurred, which was less than 50\%. They all - in 2014 - 3 expressions, in 2015 - 2, and in $2016-3$ - referred to the relationships between public officials and ordinary people (e.g., "Here is the answer to the question of whether we trust the so-called local personnel. We 
do trust them, of course. An overwhelming majority of the Russian Federation regions are governed by people from those regions, an absolute majority. But there are occasions when the elite needs new blood. That is evident. To that matter, the regions' population demand a certain replacement of the regional elites" (Putin, 2016)). Powerlessness did not emerge. The configuration of the values indicates Putin did not presume the state-driven anomie and avoided animating the extent of uncertainty among the potential redistributors of political gnosis, which means that the president omitted to produce a semantic universe characteristic of the obviating a revolutionary situation (Colgan, Lucas, 2017).

The fourth feature of political gnosis, obscurantism consists in purposeful withholding information from members of a populace. The gnostic imposes restrictions of disseminating knowledge to prevent the facts from becoming known. On the level of political obscurantism, one homogeneous criterion of a strategy of coping with non-gnostic knowledge lets us define three levels of the intensity of political gnosis. Non-gnostic knowledge is of dangerous nature because it potentially or genuinely precludes the immanentization of the eschaton, supports the external world, and menaces the internal world. Political obscurantism takes on the following values: a maximum extent of political gnosis (3) occurs when the gnostic displays overt hostility to dangerous knowledge and aims to destroy it due to its very nature. The call for fighting off non-gnostic knowledge is the exterminating attempt. A moderate extent (2) is when the gnostic presents non-gnostic knowledge as fake knowledge that misleads. The shift in the established meanings of information is the strategy of faking. A low extent (1) makes an appearance when the gnostic taboos non-gnostic knowledge by making things unmentionable. Wiping information counter to a gnostic perception is the tabooing. When a figment does not take the shape of the discursive eradication of dangerous knowledge, and it is relatively close to contributing to the discussion over diagnosed knowledge of the political meaning [0], no political gnosis appears.

Table 5

Political obscurantism in Putin's annual news conferences

\begin{tabular}{|c|c|c|c|}
\hline \multirow{2}{*}{ The intensity of political gnosis/lack of political gnosis } & \multicolumn{3}{|c|}{ A count of manifestations } \\
\hline & 2014 & 2015 & 2016 \\
\hline \multicolumn{4}{|l|}{ Political gnosis } \\
\hline Exterminating dangerous knowledge & 0 & 0 & 0 \\
\hline Faking dangerous knowledge & 8 & 14 & 18 \\
\hline tabooing dangerous knowledge & 2 & 6 & 6 \\
\hline \multicolumn{4}{|l|}{$\begin{array}{ll} & \text { Political diagnosis } \\
\end{array}$} \\
\hline Discussion over diagnosed knowledge of the political meaning & 2 & 4 & 3 \\
\hline
\end{tabular}

Source: Own study.

The configuration of gnostic and diagnostic elements points out that the former dominated in 2014-2016 (Table 5). Its frequency slightly increased over time. In 2014, 83\% of the expressions were of gnostic nature, in $2015-83 \%$, and in $2016-89 \%$. No symptom of political gnosis took on the maximum value. Putin avoided pursuing the aggressive strategy of exterminating dangerous knowledge. The president considered no information as a dangerous obstacle on Russia's political way. Oral obscurantization took on a moderate extent. Most of the manifestations consisted in altering information with their interpretation (e.g. "Are there any indications of some people going overboard, so 
to speak, in what they do? Maybe there are. This happens always and everywhere. It is essential to look into this. If the media pay attention to it, this is the best method of fighting all sorts of excesses, including with regard to the opposition. You have mentioned some of these people. Everyone is entitled to have an opinion. Everyone has a right to state his position, but I repeat, within the bounds of the law, without rocking the country and monopolizing the right to tell the ultimate truth" (Putin, 2014)). Rare were attempts to abandon dealing with questions and taboo their subject matter (e.g., "Although that is what actually happens now: we solve some issues with the European Commission and others at the national level with individual European countries" (Putin, 2016)).

Political gnosis gives temporal solutions which stem from a desire of self-perpetuation. The gnostic introduces strategies of how to survive on the historic battlefield of the clash of good and evil powers by utilizing own and foreign cultural resources which are material and non-material elements of cultures. On the level of the strategies, two homogeneous criteria of responding to non-gnostic and treating gnostic cultural resources let us determine three levels of the intensity of political gnosis. The strategies take on the following values: a maximum extent of political gnosis, annihilating contraacculturation and celebrating nativism (3) emerge if the gnostic calls for the destruction of non-gnostic cultural resources. Simultaneously, the gnostic celebrates own resources by making use of its valuable potential to survive. A moderate extent, isolating contraacculturation and preserving nativism (2) make an appearance when the gnostic comes out in favor of isolation from non-gnostic cultural resources and perpetuates own cultural facilities. A low extent, escapist contra-acculturation and reviving nativism (1) occur if the gnostic escapes from being in any relationship with non-gnostic cultural resources and restores the weakened cultural base. When a blueprint for acting does not take the form of contra-acculturative and nativist approaches toward cultural resources, and it is relatively close to an intersubjective political diagnosis of the usage of cultural resources [0], no political gnosis shows up.

Table 6

Strategies of survival on the historic battlefield in Putin's annual news conferences

\begin{tabular}{|l|r|r|r||}
\hline \multicolumn{1}{|c|}{ The intensity of political gnosis/lack of political gnosis } & \multicolumn{2}{c||}{ A count of manifestations } \\
\cline { 2 - 4 } & $\mathbf{2 0 1 4}$ & $\mathbf{2 0 1 5}$ & $\mathbf{2 0 1 6}$ \\
\hline \multicolumn{2}{|c||}{ Political gnosis } & 17 & 19 \\
\hline Annihilating contra-acculturation and celebrating nativism & 3 & 0 & 0 \\
\hline Isolating contra-acculturation and preserving nativism & 0 & 0 & 0 \\
\hline escapist contra-acculturation and reviving nativism & 0 & 14 & 18 \\
\hline \multicolumn{2}{|c|}{ Political diagnosis } \\
\hline Political diagnosis of how to use or avoid using cultural resources & 12 & 14 & 18 \\
\hline
\end{tabular}

Source: Own study.

In 2014, political gnosis entered $20 \%$ of the expressions concerning how to use or avoid using cultural resources, in $2015-55 \%$, and in $2016-51 \%$ (Table 6). A rate of political diagnosis increased over time, but it dominated only in 2014. It took the form of the discussion on the role of culture in everyday life. A frequency of gnostic elements expanded as well, and their intensity maintained the highest value. Russian strategy on the historic battlefield drew upon annihilating contra-acculturation and celebrating nativism. 
Putin called for fighting off terrorists and put forward physical annihilation as the only effective strategy to act (e.g., "The fight against terrorism, which we have not defeated yet but we have definitely broken its back - these are the results" (Putin, 2015)). Contraacculturation co-occurred with celebrating nativism (e.g., "This is actually the price we have to pay for our natural aspiration to preserve ourselves as a nation, as a civilisation, as a state" (Putin, 2014)). Russian Federation needed constant perpetuation and development instead of a revival. Putin linked preservation with the glorification of Russia to offer a means of self-reproduction and abandoned isolation and escape as the strategies of negotiating the status of the state on the historic battlefield. An insubstantial use of nativism, contra-acculturation and the configuration of political diagnosis and gnosis revealed no fear of both the loss of own culture and the foreignness threat. However, the pivotal strategy was to make a great promise of decisive actions in case of necessity.

\section{Conclusions}

The research neither draws far-fetched conclusions nor argues that Russian political regime changed. Instead, it states that despite critical junctures in domestic and foreign politics, the system was steady on the level of an epistemic apparatus disseminated by its leader. The configurations of elements of political gnosis and diagnosis reflected the persistence of Putin's gnostic semantic structures. The president reconfigured gnosis in its core political values over time. Whereas in 2014-2015, an authoritarian type dominated, in 2016, a totalitarian gnosis performed a lead role. The increase in the latter type co-occurred with the growth of democratic gnosis. As a result, however, the intensity and frequency of the types of political gnosis did not alter significantly. Gnostic but not political value-based expressions and political diagnosis supported the structure of the Great Russia. The rate of the usage of non-gnostic elements to strengthen gnostic narration was declining slightly. On the level of splitting the political universe, political gnosis was moderately intense, fallacious immanentization of the eschaton - low, manifestations of presumed anomie - low, political obscurantism - moderately, and strategies of survival on the historic battlefield - eminently. Putin consistently and widely exerted mild political gnosis to disseminate its semantic structures and did not confine the scope of recipients to Russians. The variety of the 2016 contentious politics failed to trigger off a reaction characteristic of obviating a revolutionary situation. Putin's image of the political universe was to convince us that political elites felt secure and there was no revolution threat.

\section{Bibliography}

Barceló J. (2017), National Personality Traits and Regime Type: A Cross-National Study of 47 Countries, "Journal of Cross-Cultural Psychology", vol. 48, no. 2.

Bäcker R. (2016), Kategorie teoretyczne totalitaryzmu a badania empiryczne, "Studia nad Autorytaryzmem i Totalitaryzmem", vol. 38, no. 2.

Colgan J. D., Lucas E. R. (2017), Revolutionary Pathways: Leaders and the International Impacts of Domestic Revolutions, "International Interactions: Empirical and Theoretical Research in International Relations", vol. 43, no. 3. 
Dyson S. B., Parent M. J. (2017), The operational code approach to profiling political leaders: understanding Vladimir Putin, "Intelligence and National Security", Published online: 11.04.2017.

Fagerholm A. (2016), Ideology: A proposal for a conceptual typology, "Social Science Information", vol. 55 , no. 2.

Heydari A., Davoudi I., Teymoori A. (2011), Revising the assessment of feeling of anomie: Presenting a multidimensional scale, "Procedia - Social and Behavioral Sciences", vol. 30.

Kolstø P. (2016), Crimea vs. Donbas: How Putin Won Russian Nationalist Support - and Lost It Again, "Slavic Review", vol. 75, no. 3.

Martin R. (1997), Democratic Institutions, Oxford Scholarship Online. http://www.oxfordscholarship. com/view/10.1093/0198292937.001.0001/acprof-9780198292937-chapter-7, 22.07.2017.

Miley T. J. (2011), Franquism as Authoritarianism: Juan Linz and his Critics, "Politics, Religion \& Ideology", vol. 12, no. 1.

Miley T. J. (2015), Constitutional Politics and Religious Accommodation: Lessons from Spain, "Politics, Religion \& Ideology", vol. 16, no. 4.

Motimele M. (2017), Political representation and non-citizenship: the impact of excluded subjects on democratic frameworks of representation, "Representation", Published online 10.07.2017.

Putin V. (2014), News conference of Vladimir Putin, 18.12.2014, Official Internet Resources of the President of Russia, http://en.kremlin.ru/events/president/news/copy/47250, 21.04.2017.

Putin V. (2015), Vladimir Putin's annual news conference, 17.12.2015, Official Internet Resources of the President of Russia, http://en.kremlin.ru/events/president/news/copy/50971, 21.04.2017.

Putin V. (2016), Vladimir Putin's annual news conference, 23.12.2016, Official Internet Resources of the President of Russia, http://en.kremlin.ru/events/president/news/copy/53573, 21.04.2017.

Roberts K. (2017), Understanding Putin: The politics of identity and geopolitics in Russian foreign policy discourse, "International Journal", vol. 72, no. 1.

Sussex M. (2017), The triumph of Russian national security policy? Russia's rapid rebound, "Australian Journal of International Affairs", Published online 09.07.2017.

Voegelin E. (1987), The New Science of Politics: An Introduction, The University of Chicago Press, Chicago-London.

\section{Jak zmierzyć gnozę polityczną? Przykłady empiryczne z Rosji Putina}

\section{Streszczenie}

Badanie wykorzystuje metodę analizy źródeł opierającą się na jakościowej analizie komparatystycznej wystąpień prezydenta Rosji Władimira Putina podczas dorocznych konferencji prasowych. Jego celem jest rozwiązanie problemów badawczych: jak zmieniała się gnoza polityczna w przemówieniach Putina w latach 2014-2016 podczas kolejnych konferencji? Jak Putin wyzwalał potencjał performatywny z niegnostycznych elementów dyskursu po to, żeby wzmocnić gnozę polityczną? W wyniku analizy określono jakościową zmianę polegającą na przejściu od autorytarnej do totalitarnej i demokratycznej gnozy politycznej, a także ustalono wystapienie umiarkowanego stopnia nasilenia elementów gnostycznych. Artykuł formułuje narzędzia do pomiaru typów i natężenia gnozy politycznej oraz rozróżniania diagnozy politycznej od gnozy, które są ważne dla badań z zakresu socjologii polityki i testuje ich empiryczną efektywność.

Słowa kluczowe: religia polityczna, aparat epistemiczny, struktura semantyczna, reżim polityczny, doroczna konferencja prasowa Putina 
